\title{
Isolation and characterization of a thermostable alkaline chitinase-producing Aeromonas strain and its potential in biodegradation of shrimp shell wastes
}

\author{
ZHENGANG MA ${ }^{1 *}$, JINFENG TONG ${ }^{1}$, YAN WANG ${ }^{1}$, ZEYANG ZHOU ${ }^{1}$ \\ ${ }^{1}$ Chongqing Key Laboratory of Animal Biology, Chongqing Key Laboratory of Vector Insect, Chongqing \\ Normal University, Chongqing, 401331, PR China
}

\begin{abstract}
Chitinases are employed to the conversion of chitin and are produced by a wide range of bacteria. The objective of this study was to isolate chitinase-producing microorganisms with high chitinolytic activity. A thermostable alkaline chitinase producing isolate strain CQNU6-2 was obtained from soil samples and showed potential in biodegradation of shrimp shell wastes. The optimal culturing conditions of isolate CQNU6-2 is at $25^{\circ} \mathrm{C}$ and $\mathrm{pH} 7$ for $24 \mathrm{~h}$. The chitinase produced by strain CQNU6-2 exhibited maximum activity at $\mathrm{pH} 6.0$ and $40^{\circ} \mathrm{C}$ and it could tolerate the treatment of high temperature (up to $80^{\circ} \mathrm{C}$ ) and high $\mathrm{pH}$ (over 10). Taxonomic study, based on biochemical and morphological analysis and phylogenetic analysis of $16 \mathrm{~S}$ rDNA, showed that strain CQNU6-2 was belongs to the genus Aeromonas sp. The isolate can effectively hydrolyze colloidal chitin with degradation rate of $100 \%$ and also can directly degrade the shrimp shells. Ammonium sulfate precipitation method can be used to preliminary purify the chitinase. In conclusion, strain CQNU6-2 had a promising potential for biodegradation of chitin under harsh $\mathrm{pH}$ or temperature conditions and could be employed to the comprehensive utilization of shrimp shell wastes.
\end{abstract}

Keywords Aeromonas sp., chitinase, thermostable, alkali-tolerant, shrimp shell wastes, biodegradation.

To cite this article: MA Z, TONG J, WANG Y, ZHOU Z. Isolation and characterization of a thermostable alkaline chitinase-producing Aeromonas strain and its potential in biodegradation of shrimp shell wastes. Rom Biotechnol Lett. 2021; 26(2): 2511-2522. DOI: $10.25083 / \mathrm{rbl} / 26.2 / 2511.2522$

$\triangle$ *Corresponding author: ZHENGANG MA, Ph. D., Chongqing College Town, Shapingba District, Chongqing, PR China; Zip code: 401331; Tel./Fax: +86-23-65910240

E-mail: mzgcqnu@126.com 


\section{Introduction}

Chitin is a linear polysaccharide with $\beta-1,4-\mathrm{N}$-acetylglucosamine (GlcNAc) as the basic unit. It is widely distributed in nature and known as a major structural component in the fungal cell walls, peritrophic membrane of insect gut, exoskeletons of insects, arthropods and crustaceans (ALI et al, 2020, UEDA and KUROSAWA, 2015). Chitin has become the second largest biomass resource (JHA et al, 2016) and is treated as the potential material for yielding chitosan oligosaccharides, chitin oligosaccharides and other chitin derivatives (GUAN et al, 2019). In many coastal areas, biological resources including shrimp and other crustaceans are very rich, but there are large amount of shrimp and crab shells were produced. Most produced shrimp and crab shells are discarded and piled up like mountains. Unfortunately, for chitin is insoluble substrates, most of the discarded shells became wastes which visibly wasted biological resources and polluted the environment (ALI et al, 2020, YAN and CHEN, 2015). Additionally, in the food industry and fishery, shrimp and crab shells have become the main components of produced waste (KRITHIKA and CHELLARAM, 2016). Degrading chitin into low molecular weight products is an important way to recycle the discarded chitin in the environments (RATHORE and GUPTA, 2015). Generally, physical, chemical or biological approaches can be used to decompose chitin and among which biological method, especially for the enzymatic method with chitinase, is specially focused for the advantages of good yield, environmental friendliness, mild reaction condition and high product uniformity (JUNG and PARK, 2014, LIU et al, 2019).

Chitinases are capable of catalyzing the hydrolysis of chitin. Enzymatic chitin degradation is essentially implemented by chitinases, which are found in a wide range of organisms as diverse as insects, fungi, crustaceans, plants and bacteria, and are involved in nutrition digestion, energy generation, morphogenesis, and defense against chitincontaining pathogens (UEDA and KUROSAWA, 2015, LE and YANG, 2018). Up to now, chitinolytic enzymes have been commercially employed to generate chitooligosaccharides and soluble oligomers of N-acetyl-glucosamine (GlcNAc) as part of pharmaceutical formulations. Purified chitinase has been applicated to treat chitinous waste and control malaria transmission (KIM et al, 2017, DAHIYA et al, 2006). Notably, thermostable enzymes have found lots of commercial applications in various industries (DEMIRJIAN et al, 2001), such as the chemical industries (BAHRAMI et al, 2001), the starch industry (SARIKAYA et al, 2000) and the food related industry (HAKI and RAKSHIT, 2003). Thermostable and alkaliphilic chitinase had major advantages over industrial catalysis for their high-hydrolytic activity at high temperature and $\mathrm{pH}$, which could be useful for the chitin industry and biotechnological applications (KUZU et al, 2012). Especially, their application in bioconversion of marine shellfish waste to various types of high value-added products, under alkaline and high temperature conditions, became one of the key research topics (AKTUGANOV et al, 2018).
Numerous reported bacteria, including Bacillus, Citrobacter, Paenibacillus, Sarratia, and Streptomyces genera, are well known to produce chitinases (ALIABADI et al, 2016). Screening novel microbes and analyzing the characterization of their produced enzymes become urgent for exploring diverse sources of these enzymes. Many species of chitin-degrading microbes have been screened from various environments, and their chitinases have been studied (UEDA and KUROSAWA, 2015, BHATTACHARYA et al, 2007). As the important degraders of chitin in soil, bacteria play an important role in the recycling of carbon and nitrogen resources in soil ecosystems and this make soil becomes the ideal resouce bank for screening chitinase-producing organisms (HAN et al, 2014). Most chitin-degrading prokaryotes are including the gliding bacteria, pseudomonad, vibrio, and so on. Among which, the molecular weight of bacterial chitinases usually range of 20-60 kDa (ALIABADI et al, 2016, HAN et al, 2014). Some reported bcterial chitinases also had high molecular weight ranged from 20 to $120 \mathrm{kDa}$ (ALI et al, 2020). In bacteria, the primary role of the chitinase is thought to be the digestion and utilization of chitin as a carbon and energy source (LE and YANG, 2018, HAN et al, 2014). Recently, chitinases have attracted attention for their diverse functions and widely applications in many fields, especially used to generate bioactive chitooligosaccharides and GlcNAc (LE and YANG, 2018). Thus, screening and studying the properties of different originated chitinases have become hot topics of many researches. In order to isolate chitinase-producing microorganisms with high chitinolytic activity, soil samples were collected from the site with long-term accumulation of rotten leaves in the campus of Chongqing Normal University. A chitinase-producing bacteria Aeromonas sp. strain CQNU6-2 was obtained and the production of chitinase was optimized. Additionally, enzymatic properties and its potential in biodegradation of shrimp shell waste were also investigated.

\section{Materials and Methods}

\section{Samples, culture, and isolation of chitinase-pro- ducing bacterial strains}

Putrefying soil samples were collected from the sites with long-term accumulation of rotten leaves in the campus of Chongqing Normal University, China. Chitinaseproducing bacterial strains were isolated from these samples following classical method. Briefly, $2 \mathrm{~g}$ of the sample was resuspended before settled in $200 \mathrm{~mL}$ deionized water, and the upper suspension fluid was serially diluted, $200 \mu \mathrm{L}$ of 100 times dilution were subcultured on a chitinase isolation medium (CIM) consisting of $3 \mathrm{~g}$ tryptone, $0.7 \mathrm{~g} \mathrm{~K}_{2} \mathrm{HPO}_{4}, 0.5 \mathrm{~g} \mathrm{MgSO}_{4} \cdot 7 \mathrm{H}_{2} \mathrm{O}, 0.3 \mathrm{~g} \mathrm{KH}_{2} \mathrm{PO}_{4}$, $0.02 \mathrm{~g} \mathrm{FeSO}_{4} \cdot 7 \mathrm{H}_{2} \mathrm{O}, 0.01 \mathrm{~g} \mathrm{ZnSO}_{4} \cdot 7 \mathrm{H}_{2} \mathrm{O}, 100 \mathrm{~mL}$ colloidal chitin, $15 \mathrm{~g}$ Agar powder in $1000 \mathrm{~mL}$ ultrapure water $\left(\mathrm{pH}\right.$ 7.2-7.4). Cultures were incubated at $30^{\circ} \mathrm{C}$ under aerobic conditions for 2-5 days until clear colonies appeared on the plate. The strains with transparent circles around the colonies were selected and the size of the transparent circles were measured. The strain with the largest ratio of the diameter of the transparent circle to the diameter 
of the colony was selected and then purified by plate streaking on the chitinase isolation medium (CIM).

\section{Preparation of colloidal chitin}

Colloidal chitin was prepared by the optimized method refer to Hsu and Lockwood (1975). Briefly, $10 \mathrm{~g}$ chitin (Sigma-Aldrich, St. Louis, Mo., U.S.A.) were added into $100 \mathrm{~mL} 85 \%$ Phosphoric acid and left at $30^{\circ} \mathrm{C}$ for $36 \mathrm{~h}$. Subsequently, distilled water was add to precipitate snowflake-like colloidal chitin. The precipitate was collected by centrifugation at $10000 \mathrm{~g}$ for $10 \mathrm{~min}$ at $4^{\circ} \mathrm{C}$. The colloidal chitin was washed several times with sterile distilled water till $\mathrm{pH}$ 7.0. It was freeze-dried to powder and stored at $4{ }^{\circ} \mathrm{C}$. A total of $5 \%$ colloidal chitin was used for the chitinase activity experiments.

\section{Determination of chitinase activity}

One unit of chitinase activity was defined as the amount of enzyme that released $1 \mu \mathrm{mol}$ of GlcNAc per minute at $40^{\circ} \mathrm{C}$. The determination method is as follows: the fermentation broth is centrifuged at $10000 \mathrm{~g}$ for $10 \mathrm{~min}$, and $1 \mathrm{~mL}$ fermentation supernatant plus $1 \mathrm{~mL}$ substrate reaction solution were added to $1 \mathrm{~mL}$ phosphate buffer (pH 6.0). The reaction was maintained at $40^{\circ} \mathrm{C}$ for $30 \mathrm{~min}$. Then, $1 \mathrm{~mL}$ supernatant was obtained after centrifugation at $4000 \mathrm{~g}$ for $2 \mathrm{~min}$ and mixed with $2 \mathrm{~mL} \mathrm{3,5-dini-}$ trosalicylic acid (DNS). Subsequently, the mixture was heated in boiling water bath for $10 \mathrm{~min}$ and then made up to $10 \mathrm{~mL}$ after cooling down. An absorbance at $540 \mathrm{~nm}$ exhibited the amount of released reducing sugar in the reaction mixture. The standard curve was generated from known concentrations of GlcNAc (0 to $1.6 \mathrm{mg}$ ). The enzyme activity was calculated according to the DNS method for the standard curve of GlcNAc.

\section{Morphological and phenotypic characterizations}

The selected strain was streaked on the isolation plate and cultivated for $24 \mathrm{~h}$ at $30^{\circ} \mathrm{C}$. Then, colony characteristics, including colony color, gloss, size, texture, shape, surface condition, pigment production status, etc, were recorded. For morphological characterization, a single colony was picking into the fermentation medium (FM) consisting of $3 \mathrm{~g}$ tryptone, $1.5 \mathrm{~g}$ yeast extract, $0.7 \mathrm{~g}$ $\mathrm{K}_{2} \mathrm{HPO}_{4}, 0.5 \mathrm{~g} \mathrm{MgSO} \cdot 7 \mathrm{H}_{2} \mathrm{O}, 0.3 \mathrm{~g} \mathrm{KH}_{2} \mathrm{PO}_{4}, 0.02 \mathrm{~g}$ $\mathrm{FeSO}_{4} \cdot 7 \mathrm{H}_{2} \mathrm{O}, 0.01 \mathrm{~g} \mathrm{ZnSO}_{4} \cdot 7 \mathrm{H}_{2} \mathrm{O}, 100 \mathrm{~mL}$ colloidal chitin in $1000 \mathrm{~mL}$ ultrapure water $(\mathrm{pH}$ 7.2-7.4) and cultivated for $24 \mathrm{~h}$ at $30^{\circ} \mathrm{C}$. Subsequently, the bacteria were collected by centrifugation at $12000 \mathrm{~g}$ for $2 \mathrm{~min}$. The samples were washed and postfixed in $2.5 \%$ glutaraldehyde fixative solution for $5 \mathrm{~h}$ at room temperature. Following postfixation, the sample was centrifuged at $12000 \mathrm{~g}$ for 2 min and wash with PBS buffer (PH7.4) for three times. After 1\% osmium acid was added and allowed to stand for $1 \mathrm{~h}$, it was washed again with PBS buffer (PH7.4) for three times. The samples were dehydrated in a graded ethanol series $(30 \%, 50 \%, 60 \%, 70 \%, 80 \%, 90 \%$, and $100 \%$ with each change for $15 \mathrm{~min}$ ), and subsequently treated with $50 \%$, $75 \%$ and $100 \%$ tert-butanol with each change for 10 minutes. After drying, the grains were attached to Scanning Electron Microscope stubs using doublesided conductive tape and sputter coated with gold. The samples were examined using Hitachi S-3000N Scanning Electron Microscope
(Hitachi High-Technologies Corp., Japan) with an acceleration tension of $15 \mathrm{kV}$.

\section{Taxonomic Study}

Biochemical and morphological analysis of the strain were performed following Bergey's Manual (BRENNER et al, 2005, MA et al, 2015). Total genomic DNA was extracted according to the method by Huber et al. (2002). The 16S rRNA gene was polymerase chain reaction (PCR)-amplified using the universal primers, 8F (5'-AGAGTTTGATCCTGGCTCAG-3') and 1492R (5'-ACGGTTACCTTGTTACGACTT -3') in an Eppendorf Mastercycler nexus gradient (Hamburg, Germany). The PCR mixture was consisted of $1.0 \mu \mathrm{L}$ of template DNA, $2.0 \mu \mathrm{L}$ of $2.5 \mathrm{mM}$ dNTPs, $2.0 \mu \mathrm{L}$ of $2.5 \mathrm{mM} \mathrm{MgCl}_{2}, 2.5 \mu \mathrm{L}$ of $10 \times \mathrm{PCR}$ buffer $\left(\mathrm{Mg}^{2+}\right.$ free $), 1.0 \mu \mathrm{L}$ of each primer $(10 \mathrm{mM}), 0.25 \mu \mathrm{L}$ of rTaq DNA polymerase $(2.5 \mathrm{U} / \mu \mathrm{L})$ (TaKaRa, Dalian), in a final volume of $25 \mu \mathrm{L}$. Samples were preheated for $10 \mathrm{~min}$ at $94^{\circ} \mathrm{C}$ and then amplified for 35 cycles at $94^{\circ} \mathrm{C}$ for $20 \mathrm{~s}, 55^{\circ} \mathrm{C}$ for $30 \mathrm{~s}$, and $72^{\circ} \mathrm{C}$ for $80 \mathrm{~s}$; $72^{\circ} \mathrm{C}$ for $10 \mathrm{~min}$. Subsequent to PCR amplification, $2 \mu \mathrm{L}$ of each reaction was run on a $0.8 \%$ agarose gel, and the DNA was visualized by UV illumination at BIO-RAD Gel Doc 2000 (Hercules, California, USA) followed with ethidium bromide staining. Then, the 16S rDNA gene was cloned into pMD19-T vector. Nucleotide sequence of $16 \mathrm{~S}$ rDNA was sequenced and identified through the online BLAST program. Multiple alignment was completed with the CLUSTAL W software and a neighborjoining phylogenetic tree was reconstructed using the MEGA 7 with performing 1000 replicates and marked into branching points (RASTOGI et al, 2009, HAN et al, 2014, MA et al, 2015).

\section{Effect of media type on strain growth and chitinase production}

Six different media were used to study their effect on the growth of strain and chitinase production. The basic medium (BM) was $3 \mathrm{~g}$ tryptone, $0.7 \mathrm{~g} \mathrm{~K}_{2} \mathrm{HPO}_{4}, 0.5 \mathrm{~g}$ $\mathrm{MgSO}_{4} \cdot 7 \mathrm{H}_{2} \mathrm{O}, 0.3 \mathrm{~g} \mathrm{KH}_{2} \mathrm{PO}_{4}, 0.02 \mathrm{~g} \mathrm{FeSO}_{4} \cdot 7 \mathrm{H}_{2} \mathrm{O}, 0.01 \mathrm{~g}$ $\mathrm{ZnSO}_{4} \cdot 7 \mathrm{H}_{2} \mathrm{O}$, $15 \mathrm{~g}$ Agar powder in $1000 \mathrm{~mL}$ ultrapure water $(\mathrm{pH} 7.2-7.4)$. The tested media was basic medium containing $0.5 \%$ colloidal chitin (CBM), Glucose basic medium containing $0.5 \%$ Glucose (GBM), Shrimp basic medium containing $0.5 \%$ shrimp shell powder (SBM), Luria-Bertani (LB) broth and Shrimp Luria-Bertani medium (SLB) with $0.5 \%$ shrimp shell powder. The strain was then streaked to the above mediums and cultivated for $48 \mathrm{~h}$ at $30^{\circ} \mathrm{C}$. In order to evaluate the growth of bacteria more clearly, the cells of CQNU6-2 were gradient diluted and then the same quantity bacterium was coated on the above mediums. Three repeated plates were performed for each cultural medium. The colony growth status and transparent circle were observed.

\section{Optimization of culturing conditions for enzyme activity}

The bacterial cultures were inoculated into the fermentation medium (FM) with $2 \%$ inoculation volume. Under the cultural condition of $180 \mathrm{r} / \mathrm{min}$ in constant temperature incubator, the effects of different initial $\mathrm{pH}$ $(5,6,7,9$ and 11$)$, different culture temperature $\left(20^{\circ} \mathrm{C}\right.$, $25^{\circ} \mathrm{C}, 30^{\circ} \mathrm{C}, 37^{\circ} \mathrm{C}$ and $42^{\circ} \mathrm{C}$ ) and different culture time 
$(12 \mathrm{~h}, 24 \mathrm{~h}, 36 \mathrm{~h}$ and $48 \mathrm{~h})$ on chitinase activity were explored. At the end of the growth period, chitinase activity assay was performed by the stated protocol above. All experiments were performed independently in triplicate.

\section{Effect of reaction conditions and stability for enzyme activity}

To investigate the effect of temperature on chitinase activity, a standard assay was performed at various temperatures $\left(10^{\circ} \mathrm{C}, 20^{\circ} \mathrm{C}, 30^{\circ} \mathrm{C}, 40^{\circ} \mathrm{C}, 50^{\circ} \mathrm{C}, 60^{\circ} \mathrm{C}, 70^{\circ} \mathrm{C}\right.$, $80^{\circ} \mathrm{C}$ and $\left.90^{\circ} \mathrm{C}\right)$. Thermal stability was determined by incubating the crude enzyme at various temperature (from $20-90^{\circ} \mathrm{C}$ ) for $3 \mathrm{~h}$ under $\mathrm{pH} 7.0$ and then measured the chitinase activity under standard assay conditions (KUZU et al, 2012). The effect of $\mathrm{pH}$ on chitinase activity were assessed over the range of $\mathrm{pH}$ 3-10 under standard assay conditions with different buffers as follows: citrate buffer (50 mM, pH 3, 4 and 5), phosphate buffer (50 mM, pH 6, 7, and 8), and borate buffer (50 mM, pH 9 and 10) (UEDA and KUROSAWA, 2015). For pH stability assay, the enzyme solution was pre-incubated in different buffers of $\mathrm{pH}$ range from 3-10 and then the residual activity was determined under standard conditions (GUO et al, 2017). Additionally, Effect of ions and additives on enzyme activity were explored by adding $\mathrm{Na}^{+}, \mathrm{Ca}^{2+}, \mathrm{Cu}^{2+}, \mathrm{Mn}^{2+}$, $\mathrm{Fe}^{3+}, \mathrm{Zn}^{2+}, \mathrm{Mg}^{2+}, \mathrm{K}^{+}, \mathrm{Ba}^{2+}$, Urea, EDTA at high concentration of $0.1 \mathrm{mM}$ and low concentration of $0.01 \mathrm{mM}$. Chitinase activity was measured according to the standard procedure. The relative activity was calculated with the reaction, which performed in the absence of any additive, as the control. All experiments were repeated independently for three times.

\section{Growth curve and degradation experiment of colloidal chitin}

The cell growth was monitored at $600 \mathrm{~nm}$ using an UV-spectrophotometer (Lingguang 722S UV spectrophotometer, Lingguang Ltd, Shanghai, China) at different times from $3-36 \mathrm{~h}$. The strain was cultured at $30^{\circ} \mathrm{C}$ in liquid chitinase isolation medium (LCIM) with $180 \mathrm{r} / \mathrm{min}$ in constant temperature incubator. In order to explore the degradation rate of colloidal chitin, six experimental groups are set up for different culture times $(0 \mathrm{~h}, 8 \mathrm{~h}, 12 \mathrm{~h}, 24 \mathrm{~h}, 30 \mathrm{~h}$ and $48 \mathrm{~h}$ ). The bacterial cultures were inoculated into the LCIM with $2 \%$ inoculation volume and cultivated at $30^{\circ} \mathrm{C}$ with $180 \mathrm{r} / \mathrm{min}$ in constant temperature shaking incubator. The fermentation broth was collected after fermentation, centrifuged at $3000 \mathrm{r} / \mathrm{min}$ for $2 \mathrm{~min}$ to collect and weigh the undegraded chitin to calculate the degradation rate of chitin. All experiments were repeated independently for three times.

\section{Degradation experiment of Shrimp shells}

Shrimp shells were collect from the shrimp shell waste and were washed with deionized water. The shells were heated in boiling water bath for 5 min and soaked for $24 \mathrm{~h}$. Subsequently, an electric thermostatic blast drying oven was employed to remove the water for $30 \mathrm{~min}$. Then, $0.2 \mathrm{~g}$ shrimp shells were added into $30 \mathrm{~mL}$ liquid basic medium (LBM) consisted of $3 \mathrm{~g}$ tryptone, $0.7 \mathrm{~g} \mathrm{~K}_{2} \mathrm{HPO}_{4}$, $0.5 \mathrm{~g} \mathrm{MgSO}_{4} \cdot 7 \mathrm{H}_{2} \mathrm{O}, 0.3 \mathrm{~g} \mathrm{KH}_{2} \mathrm{PO}_{4}, 0.02 \mathrm{~g} \mathrm{FeSO}_{4} \cdot 7 \mathrm{H}_{2} \mathrm{O}$, $0.01 \mathrm{~g} \mathrm{ZnSO}_{4} \cdot 7 \mathrm{H}_{2} \mathrm{O}$ in $1000 \mathrm{~mL}$ ultrapure water $(\mathrm{pH} 7.2-7.4)$. All experiments were performed independently in triplicate. To study the effect degradation rate, six experimental groups are set up for different culture times $(1 \mathrm{~d}, 2 \mathrm{~d}, 3 \mathrm{~d}$, $4 \mathrm{~d}, 5 \mathrm{~d}$ and $6 \mathrm{~d}$ ). The bacterial cultures were inoculated into the LBM with $2 \%$ inoculation volume and cultivated at $30^{\circ} \mathrm{C}$ with $180 \mathrm{r} / \mathrm{min}$ in constant temperature shaking incubator. After incubating for corresponding period, the remaining shrimp shells in the triangular flask were took out and put into electric thermostatic blast drying oven for $30 \mathrm{~min}$ to remove the water. The weight of the sample was obtained and used for the calculation of degradation rate and construction of the shrimp shell degradation rate curve.

\section{Results}

\section{Isolation of chitinase-producing bacterial strains}

A total of 6 morphologically different chitinolytic bacterial colonies were screened from 6 collected soil samples. On the basis of diameter of transparent circle $(>0.2 \mathrm{~cm})$ on a chitinase isolation medium (CIM), 1 colonies named CQNU6-2 were selected for secondary screening and purification (Fig. 1A), because that the ratio of diameter of transparent circle to colony diameter reached 3.05. Three parallel assessments were conducted for purifying the colonies and the testing of enzyme activity (Fig. 1B). The selected strain CQNU6-2 exhibited the maximum chitinase activity on CIM with $0.5 \%(\mathrm{w} / \mathrm{v})$ colloidal chitin, showing clear transparent circle around colonies. The strain CQNU-6-2 grew fast and the colonies were looser and milky white with smooth surface. The colonies were slightly protruding with neat edges. Scanning electron microscopic investigations revealed the morphology of the isolated strain (Fig. 1C). The results showed that the cells were rodshaped with raised at both ends. Both ends of the cell are blunt and the size is $(0.79$ to $1.37 \mu \mathrm{m}) \times(0.44$ to $0.49 \mu \mathrm{m})$.
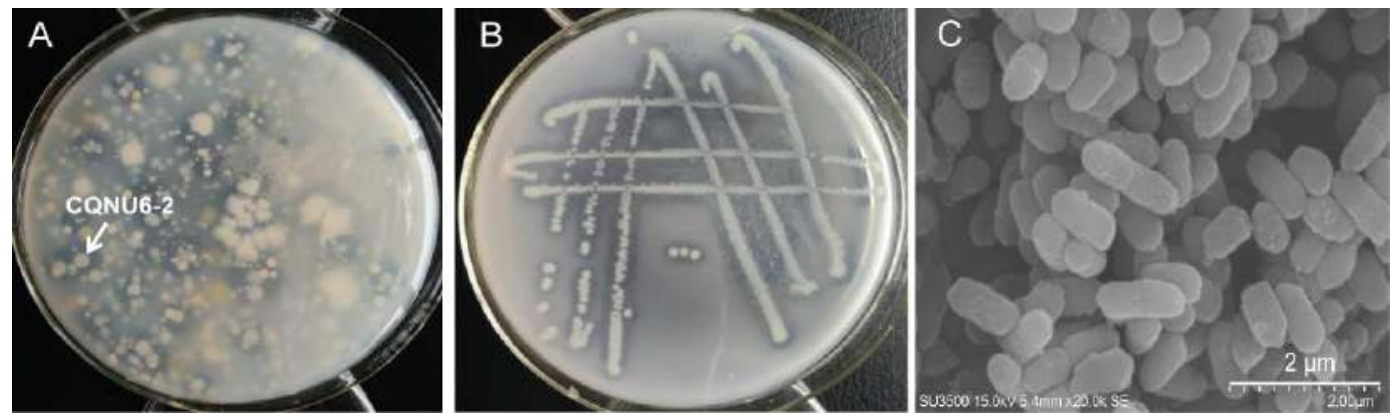

Figure 1. Screening of and re-screening of chitinase producing strains (A), purification of CQNU6-2 (B) and Electron microscopic observation on the morphology of strain CQNU6-2 strain (C). 
To test the chitinolytic activity, CQNU6-2 strain was cultured in LCIM medium and the cell-free supernatant was collected as crude enzyme for the activity assay. Results showed that the activity of chitinase was $0.415 \mathrm{U} / \mathrm{mL}$. These activities were stronger than those of Pseudomonas (LIU et al, 2019) and Bacillus licheniformis (SLIMENE et al, 2015). Strain CQNU6-2 was stored at the Chongqing Key Laboratory of Animal Biology, Chongqing Normal University, Chongqing, China.

Identification of the selected bacterial isolate CQNU6-2 After Gram staining, the isolates CQNU6-2 appeared under the light microscope as Gram-negative bacterium. The cells were rod-shaped $(0.44-0.49$ by $0.79-1.37 \mu \mathrm{m})$ and were facultative anaerobic bacteria. CQNU6-2 could utilize glucose and fructose as the carbon source. The contact enzymatic reaction exhibited a negative result. Other biochemical properties were listed in Table 1. All the properties were in accordance with the standard identification of Aeromonas in the Bergey's Manual of systematic Bacteriology (BUCHANAN and GIBBONS, 1975), the CQNU6-2 was classified as a bacteria belongs to the genus Aeromonas.

Table 1. Biochemical and physiological tests of strain CQNU6-2

\begin{tabular}{lclc}
\hline Test items & Result & Test items & Result \\
\hline Gram stain & - & Glycerol hydrolysis & + \\
Glucose & + & Sorbose & - \\
Sucrose & - & Xylose & - \\
Fructose & + & Contact enzyme reaction & - \\
Maltose & + & Acetyl methyl methanol & + \\
Trehalose & + & (V.P.) & + \\
Starch hydrolysis & + & Esculin test & + \\
\hline+ Positive, - Negative & & &
\end{tabular}

PCR was used to obtain the $16 \mathrm{~S}$ rDNA gene fragment (Fig. 2A) and partial $16 \mathrm{~S} r D N A$ sequence of strain CQNU6-2 was determined (GenBank No. MT463495) and the BLAST results showed that its share of more than $99 \%$ identifies it with those of Aeromonas at nucleic acid level. Based on multiple alignments of all related $16 \mathrm{~S} r D N A$ sequences comprised of sixteen sequences derived from ten Aeromonas and six elements from other species, the NJ phylogenetic tree was constructed for further identification. Strain CQNU6-2 is the member of clade comprised of various Aeromonas strains (Fig. 2B). This result confirmed the strain as being Aeromonas sp.

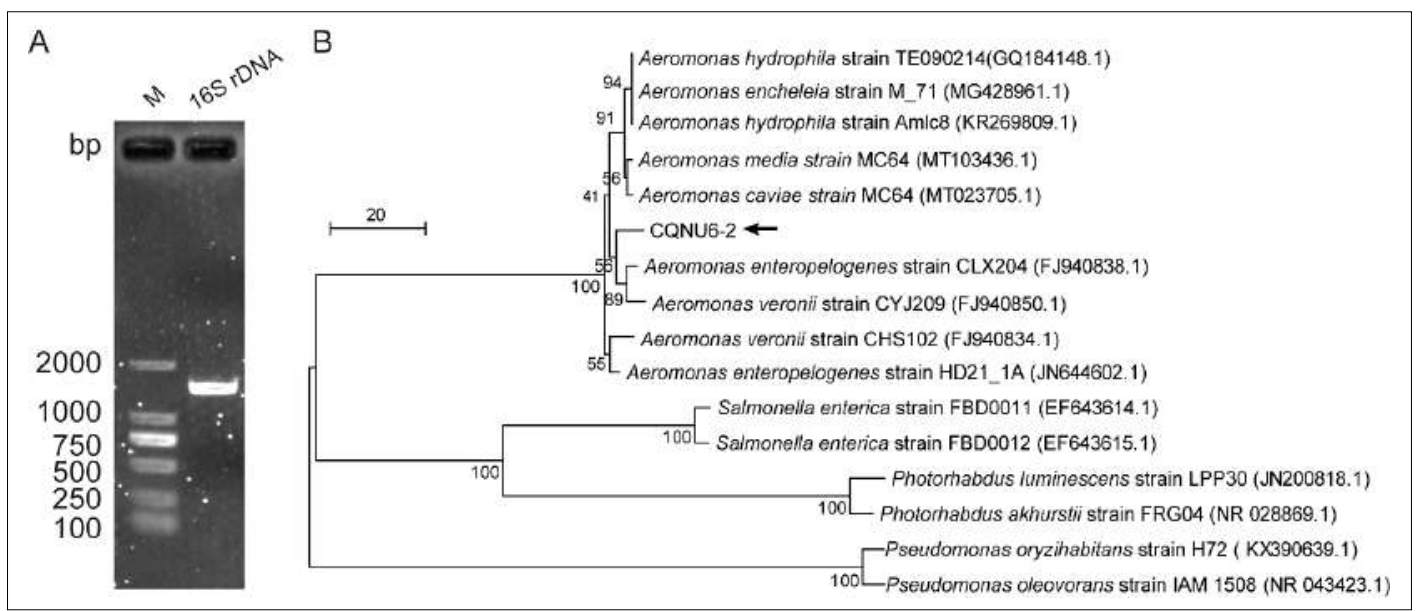

Figure 2. Analysis of $16 S r D N A$ fragment (A) and Phylogenetic analysis based on $16 S r D N A$ sequences (B) showing the position of strains CQNU6-2. The tree was constructed using the neighbor-joining method. Numbers at nodes represent the bootstrap percentage (based on 1000 replicates). The GenBank accession number is provided following the species name.

Optimization of culturing conditions of isolate CQNU6-2

To obtain an suitable cultural time for producing chitinase, four different cultural time $(12 \mathrm{~h}, 24 \mathrm{~h}, 36 \mathrm{~h}$ and $48 \mathrm{~h}$ ) were explored (Fig. 3A). It was observed that the enzyme activity was higher when the cultural time was 24 to $36 \mathrm{~h}$. And the enzyme activity significantly decreased after $48 \mathrm{~h}$ of culture. Therefore, the fermentation time of CQNU6-2 strain should be controlled within 24-36 h.
Moreover, five different cultural $\mathrm{pH}(5,6,7,9$ and 11) has been selected to study the enzyme production by strain CQNU6-2 (Fig. 3B). The Maximum activity was showed in the $\mathrm{pH} 7$ and $>50 \%$ of its maximum activity was observed in the $\mathrm{pH}$ range of 6 to 9 . The chitinase can be stable and maintained under both neutral and alkaline culture conditions. Additionally, it was exhibited that the chitinase produced by strain CQNU6-2 had maximum 
chitinase activity under the cultural temperature at $25^{\circ} \mathrm{C}$, the chitinase activity declined markedly at temperature of $42^{\circ} \mathrm{C}$, when only $21 \%$ of its initial activity retained (Fig. 3C). This result indicated that the chitinase can be produced at a lower temperature than other bacterial isolates, such as Salinivibrio (LE and YANG, 2018), Cohnella (ALIABADI et al, 2016), Paenibacillus (HAN et al, 2014), and so on.
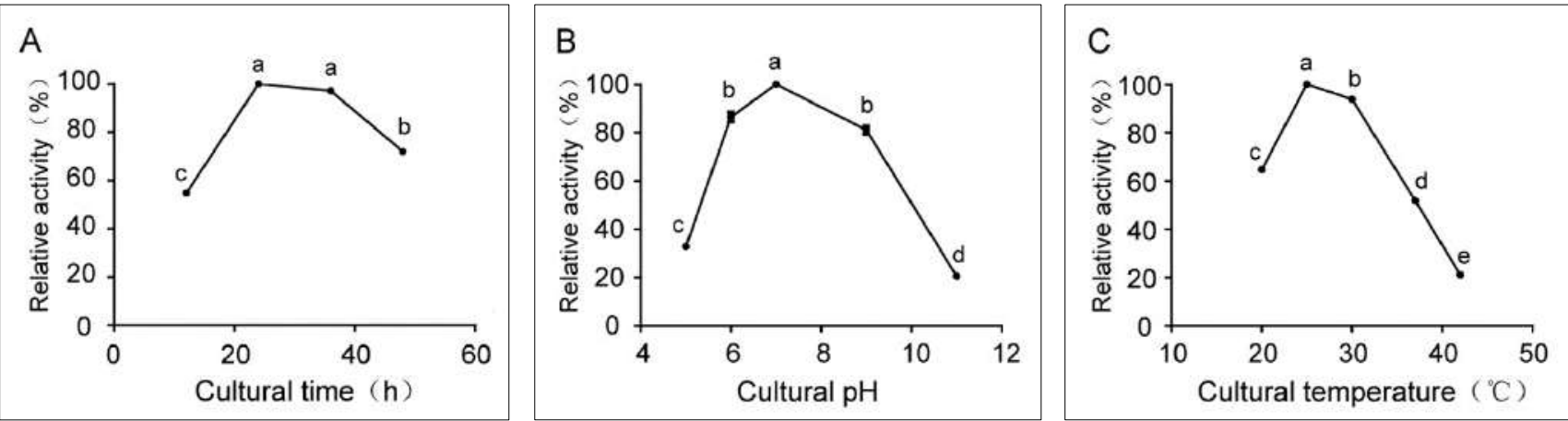

Figure 3. Effect of fermentation conditions on enzyme activity of CQNU6-2 strain

(A) Cultural time; (B) Cultural pH; (C) Cultural temperature.

\section{Enzymatic characterization of chitinase produced by strain CQNU6-2}

After optimizing the cultural conditions of enzyme production, the highest enzyme activity of the crude enzyme of strain CQNU6-2 was $0.415 \mathrm{U} / \mathrm{mL}$, which was $71.3 \%$ higher than the strain before optimization. The chitinase activity was as high as chitinases produced by other reported Aeromonas (GUO et al, 2004, AL-AHMADI et al, 2008).

In order to determine the optimum $\mathrm{pH}$ of the chitinase, the chitinase activity was measured under different reaction $\mathrm{pH}$ (from 3 to 10). The optimal reaction $\mathrm{pH}$ of this enzyme is 6 and $>50 \%$ of its maximum activity was observed in the $\mathrm{pH}$ range from 4 to 10 . It also showed $60.1 \%$ activity when the reaction $\mathrm{pH}$ at 10 . With regard to $\mathrm{pH}$ stability, the enzyme was stable over a broad $\mathrm{pH}$ range from 3 to 10 . The residual enzyme activity was $79.8 \%$ at $\mathrm{pH} 10$. However, the activity was much lower at an acidic $\mathrm{pH}$, in particular, approximately $39.3 \%$ of its activity was observed (Fig. 4A).

The optimum temperature for the chitinase were determined by varying the reaction temperature. Among all the tested temperature, the chitianse activity began at $10^{\circ} \mathrm{C}$ and achieved its maximum level at $40-50^{\circ} \mathrm{C}$ (Fig. 4B).
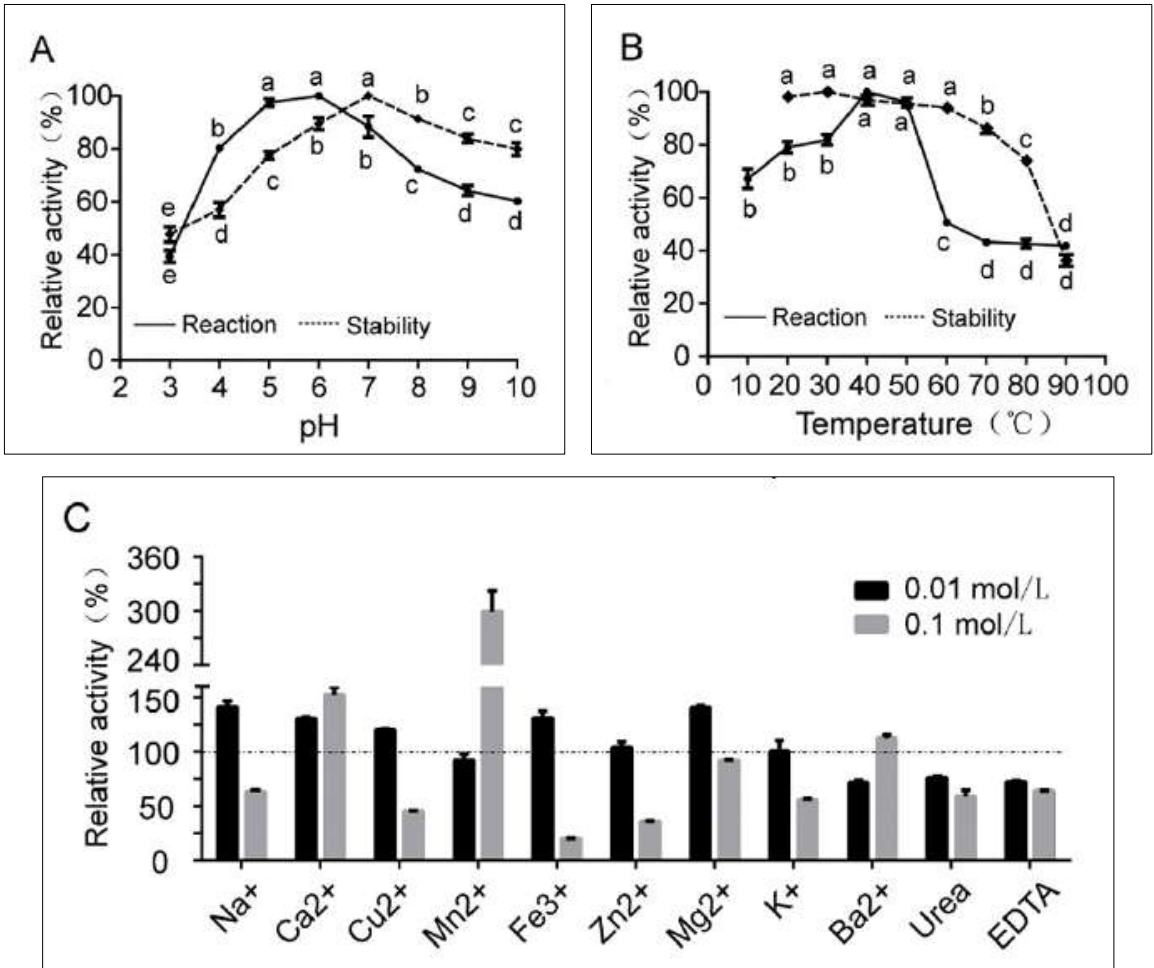

Figure 4. Effect of pH (A), temperature (B) and additives (C) on enzyme activity of CQNU6-2 strain. Chitinase activity was measured according to the standard procedure. The relative activity was calculated with the reaction, which performed in the absence of any additive, as the control. 
Strain CQNU6-2 also exhibited $67.2 \%$ of the optimized activity at low temperature of $10^{\circ} \mathrm{C}$. Chitinase activity increased from 10 to $50^{\circ} \mathrm{C}$ and then declined at temperature of 60 to $90^{\circ} \mathrm{C}$. Notably, the chitinase also could effectively hydrolyze chitin (> 40\%) when the reaction temperature high to $90^{\circ} \mathrm{C}$. It was stable at temperatures up to $80^{\circ} \mathrm{C}$ with $73.9 \%$ of the optimized enzyme activity. It showed a significantly decline when the temperature up to $90^{\circ} \mathrm{C}$ and the residual enzyme activity reduced to $36.2 \%$. In contrast, most previously reported bacteria did not functionally work under the wide range of temperature and $\mathrm{pH}$ (STUMPF et al, 2019, DAS et al, 2019). The chitinase produced by the strain CQNU6-2 had a wide temperature range of catalytic activity and exhibited extremely strong heat-resistance, so it may have potential application under high-temperature production conditions.

The crude chitinase activity was analyzed under the optimum $\mathrm{pH}$ and temperature by adding various metal ions and chemical compounds (Fig. 4C). Metal ions such as $\mathrm{Na}^{+}$, $\mathrm{Fe}^{3+}$ and $\mathrm{Mg}^{2+}$ increased the enzyme activity up to $40 \%$ at $0.01 \mathrm{mM}$, but when the concentration reached $0.1 \mathrm{mM}$, $\mathrm{Cu}^{2+}, \mathrm{Fe}^{3+}$ and $\mathrm{Zn}^{2+}$ inhibited the enzyme activity up to $50 \% . \mathrm{Ca}^{2+}$ and $\mathrm{Mn}^{2+}$ could increase the activity at $0.01 \mathrm{mM}$ up to $50 \%$. Urea and EDTA always decreased the activity at both $0.01 \mathrm{mM}$ and $0.1 \mathrm{mM}$. This effect of EDTA was not identical to the previous study of Cohnella sp. (ALIABADI et al, 2016).

\section{Analysis of chitin utilization and degradation rate of strain CQNU6-2}

In order to investigate the growth of strains on different nutrient types of media, the experiment of strain CQNU6-2 chitin utilization assay was shown in Fig. 5. The results suggested that CBM containing $0.5 \%$ colloidal chitin is most suitable for CQNU6-2 growth, showing the largest (Fig. 5B) and closely arranged colonies (Fig. 5A). Meanwhile, a clear transparent area could be observed around the colonies, which indicated the chitinase was secreted and hydrolyzed the colloidal chitin. CQNU 6-2 also could form the close colonies and weak chitin degradation area (Fig. 5A), which suggested the strains could have a better growth status and more colonies on SBM and SLB than BM and LB. Notably, the colonies on GBM with $0.5 \%$ glucose were more and larger than the medium without chitin (BM) (Fig. 5B). Although the results showed that strain CQNU6-2 could grow in the above 6 types of medium, it showed better status on the medium containing chitin, shrimp shell powder. Thus, colloidal chitin and shrimp shell powder could be suggested as the ideal source of nutrients for this strain.
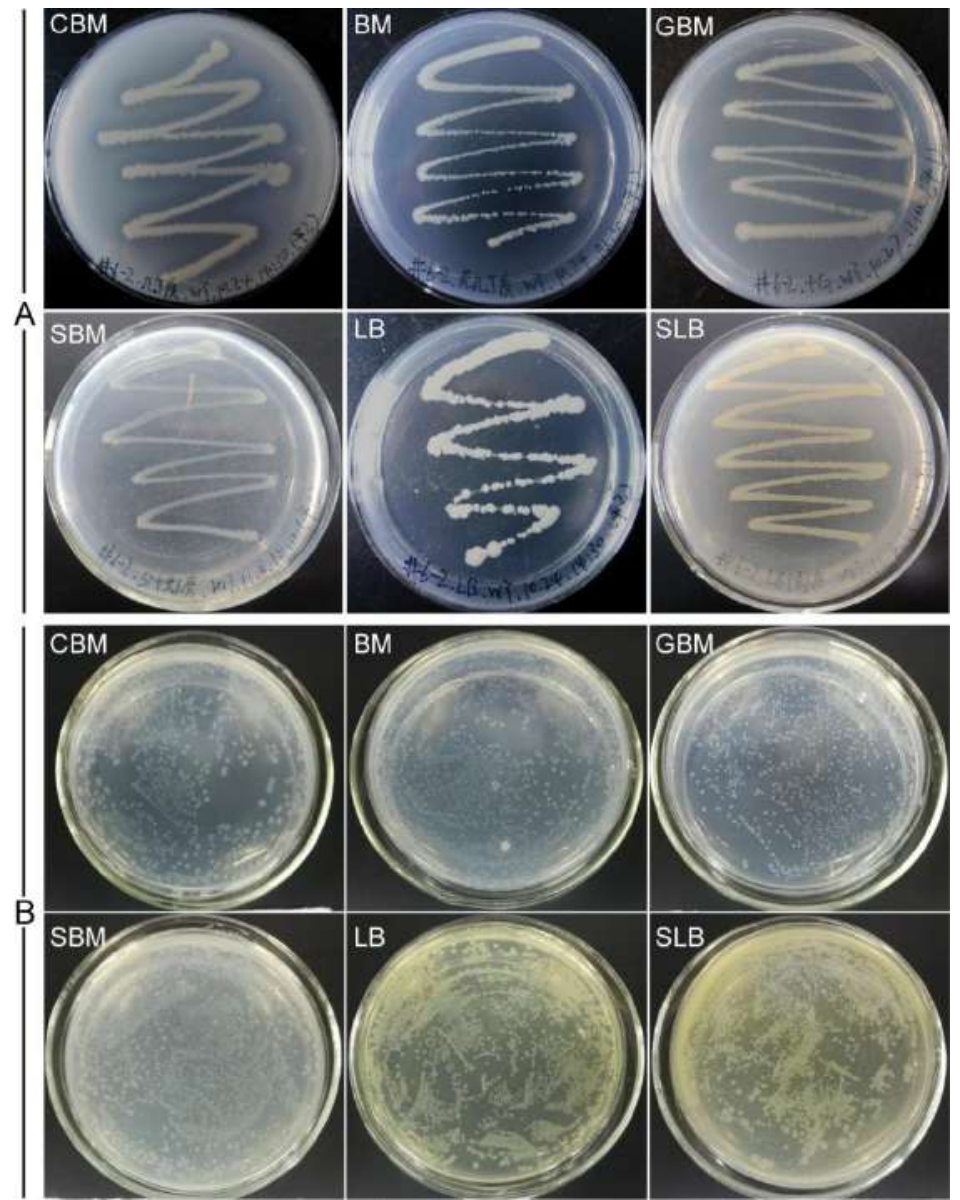

Figure 5. Analysis of chitin utilization of strain CQNU6-2. The tested media was basic medium (BM), Chitin basic medium containing $0.5 \%$ colloidal chitin (CBM), Glucose basic medium containing $0.5 \%$ Glucose (GBM), Shrimp basic medium containing 0.5\% shrimp shell powder (SBM), Luria-Bertani (LB) broth and Shrimp Luria-Bertani medium with $0.5 \%$ shrimp shell powder (SLB). The strain was then streaked (A) or coated (B) to the above mediums and cultivated for $48 \mathrm{~h}$ at $30^{\circ} \mathrm{C}$. 
Since strain CQNU6-2 can grow well on plates containing colloidal chitin and shrimp shell powder, the degradation rate of colloidal chitin was further explored. Firstly, the growth situation of CQNU6-2 in a liquid medium containing colloidal chitin (LCIM) was observed, and the growth curve was drawn according to the $\mathrm{OD}_{600}$ of the bacteria (Fig. 6). The result demonstrated that the cells, which cultured under at $30^{\circ} \mathrm{C}$ with shaking culture at $180 \mathrm{r} / \mathrm{min}$, reached the maximum growth rate at $12 \mathrm{~h}$ post inoculation (hpi), and the cell concentration raised up to the maximum and entered the stationary phase at $21 \mathrm{hpi}$.

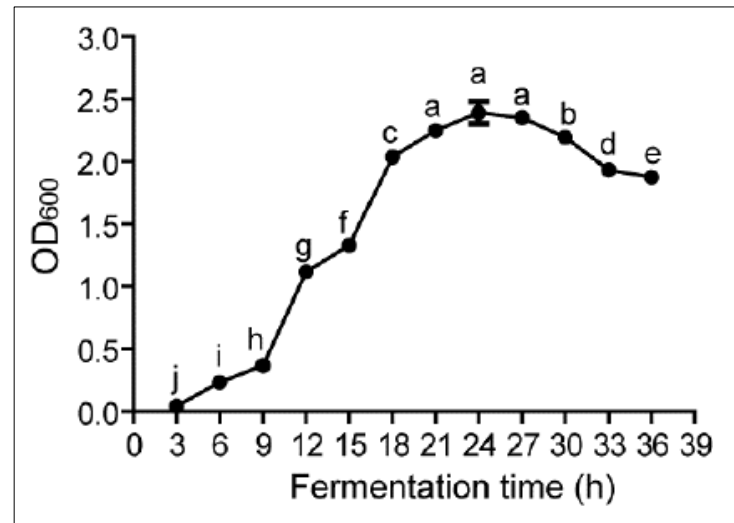

Figure 6. Determination of growth curve of strain CQNU6-2.

Degradation of shrimp shell waste of strain CQNU6-2

Strain CQNU6-2 exhibited a high degradation rate of colloidal chitin and could express a well growth status on SBM and SLB with shrimp shell power added. For further exploring its potential application in biodegradation of shrimp shells in food waste, the degradation rate of integral shrimp shells were carried out. According to the procedure mentioned above, shrimp shells were added to the liquid basic medium (LBM). After inoculation with CQNU6-2, fermentation culture was carried out at $30^{\circ} \mathrm{C}$ and $180 \mathrm{r} / \mathrm{min}$. With the extension of the cultivation time, the concentration of bacteria in the erlenmeyer flask gradually increased
From $30 \mathrm{hpi}$, the cell concentration was gradually decreased and the cells entered the decline phase.

Subsequently, the strain CQNU6-2 was cultured at $30^{\circ} \mathrm{C}$ with $180 \mathrm{r} / \mathrm{min}$ rotation speed and the degradation rate of the substrate colloid chitin at different culture times were analyzed (Fig. 7). The results showed that the chitin degradation rate of the strain reached $50 \%$ after 12 hours culture, up to $100 \%$ after 30 hours culture. It indicated that the strain has a strong degradation ability to colloid chitin substrate.

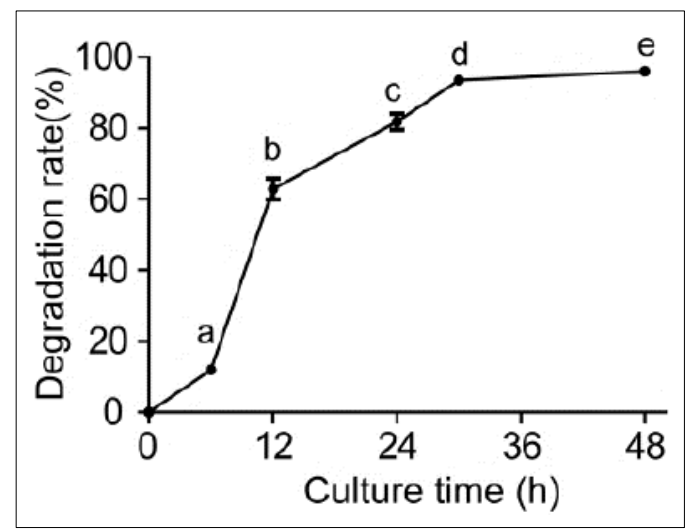

Figure 7. Analysis of colloidal chitin degradation curve of strain CQNU6-2.

and after 1 day post inoculation (dpi), the shrimp shells were degraded from intact to shrimp shell fragments. From 2 dpi to $6 \mathrm{dpi}$, the shrimp shell fragments were gradually degraded into debris (Fig. 8A). Then, the degradation rate curve was drawn (Fig. 8B) and it showed that the degradation speed was up to the maximum after 2 days post inoculation. Until $4 \mathrm{dpi}$, the degradation rate reached the maximum, about $65 \%$. From 4 dpi to $6 \mathrm{dpi}$, the degradation curve was flat and the quality of residual shrimp shells tended to be stable. The remaining ingredients may be other substance of the shrimp shells, such as proteins and glucans (KRITHIKA and CHELLARAM, 2016).
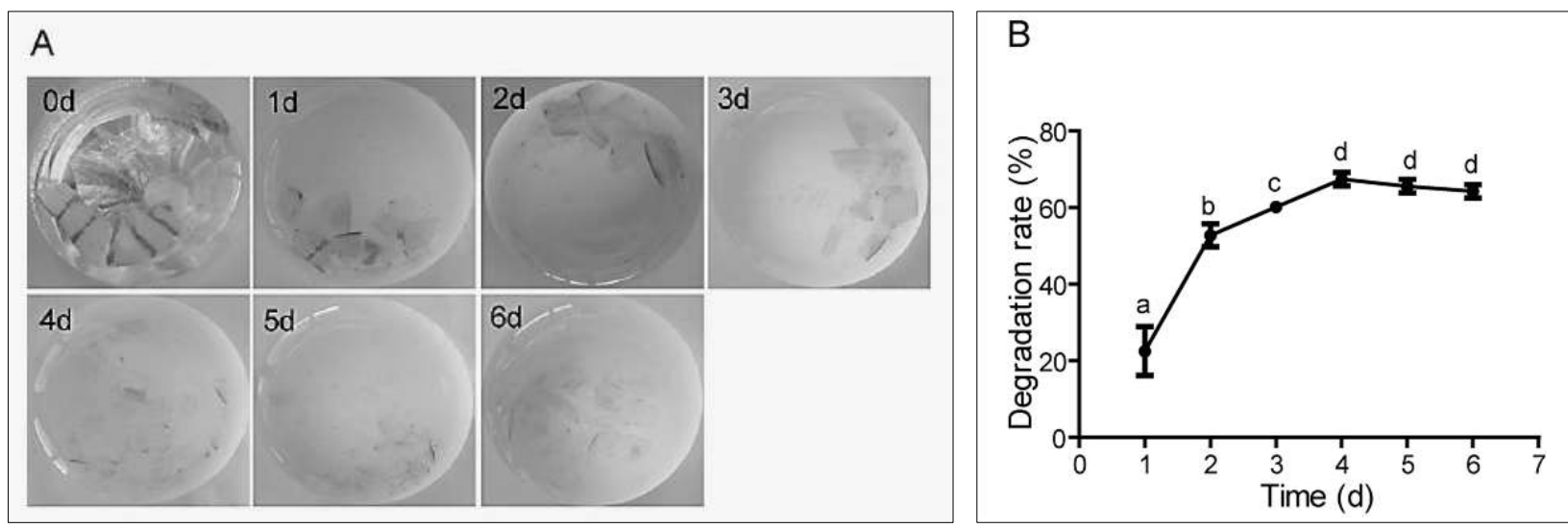

Figure 8. Shrimp shells degradation experiment (A) and analysis of shrimp shells degradation curve (B) of strain CQNU6-2. 


\section{Preliminary isolation of crude chitinase by ammonium sulfate precipitation}

In order to further isolate the chitinase from the fermentation supernatant of CQNU6-2, ammonium sulfate precipitation method was employed and the chitinase activity was determined by active plate detection and DNS method (Fig. 9A). The result indicated that the optimal fractionation range of chitinase is $30 \%-50 \%$ of ammonium sulfate saturation. The activity of chitinase isolated reached to the maximum when the saturation of ammonium sulfate was $40 \%$ (Fig. 9B). This assay would lay a solid experimental foundation for the subsequent purification of the chitinase produced by strain CQNU6-2.
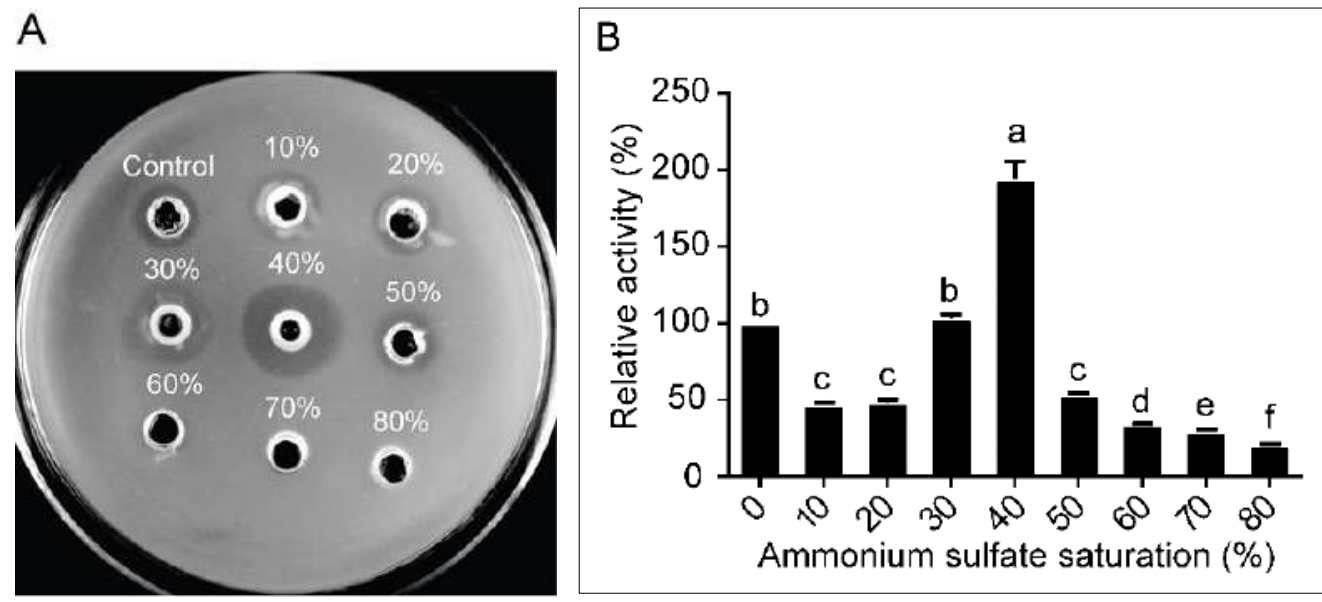

Figure 9. Ammonium sulfate precipitation of chitinase from strain CQNU6-2.
A. Enzyme activity detection of chitinase on screening plate;

B. Enzyme activity of chitinase measured by DNS method.

\section{Discussion}

Chitin exists naturally and becomes the second most abundant carbohydrate polymer around the world. Biomass with high proportions of chitin, including shrimp, crab and krill, has already been widely used for generating active substances in agriculture, medicine and food industries (LE and YANG, 2019). However, degradation and application of chitin were so difficult that large amount of shrimp waste generated from shellfish industry. Meanwhile, the utilization of chitin resources became extremely essential for proper carbon-nitrogen balance (BHATTACHARYA et al, 2016). Comparing to physical and chemical methods, biological approaches can perform more advantages to decompose chitin, including good yield, environmental friendliness and so on (LIU et al, 2019). More and more studies focused on the screening and utilization of novel chitinase-producing organisms (STUMPF et al, 2019, KUMAR et al, 2017). In this study, a thermostable alkaline chitinase-producing strain was isolated from the oil samples collected from the site with long-term accumulation of rotten leaves and confirmed to be Aeromonas sp. CQNU6-2 based on the taxonomic study including biochemical and morphological analysis, and the phylogenetic analysis of $16 \mathrm{~S}$ rDNA. Chitinase have been found in many organisms (LIU et al, 2019) and Chitinase genes have been cloned from diverse bacterial groups (HAN et al, 2014). Several species of Aeromonas, including Aeromonas caviae (CARDOZO et al, 2017, CARDOZO et al, 2019), Aeromonas hydrophila (ZHANG et al, 2017, STUMPF et al, 2019) and Aeromonas veronii (KANG et al, 2016), were reported to produce chitinase and have great potential application in the biosynthesis of pullulanase and chitinase, the bioconversion of $\alpha$-chitin into $\mathrm{N}$-acetyl-glucosamine, the degradation of chitin within fungal mycelium.

The rapid and ecofriendly chitinase production by microorganisms shows great promise of possible applications in many industries. However, several deficiencies of chitinase, including critical reaction conditions, low enzyme activity and complex purification procedures of crude enzyme, hindered their application in industries (LE and YANG, 2019). Excellent applicability of chitinase with activity under wide reaction range of $\mathrm{pH}$ and temperature would perform high potential in process of bioconversion. The $\mathrm{pH}$ and temperature effect on the crude chitinase activity of Aeromonas sp. CQNU6-2 were determined and the enzyme was active at broad range of $\mathrm{pH}$ from 3 to 10 and the activity reach to the maximum at $\mathrm{pH}$ 6. The result suggested that this chitinase could exhibit high activity under more alkaline conditions and alkaline chitinase was reported to have a certain bacteriostatic effect in vitro. Thus, the reported chitinase has the potential to be developed as an inhibitor of pathogenic bacteria and used in the biological control of pests and diseases (AJAYI et al, 2016). Additionally, enzyme can hydrolyze chitin $(>40 \%)$ at reaction temperature of 10 to $90^{\circ} \mathrm{C}$ and $67.2 \%$ of the optimized activity at low temperature of $10^{\circ} \mathrm{C}$ was observed. Even the temperature 
was high to $90^{\circ} \mathrm{C}$, it had shown $41.9 \%$ retain activity. The analysis of stability of enzyme also showed the crude chitinase was able to tolerate wide range of $\mathrm{pH}(3-10)$ and temperature at 20 to $80^{\circ} \mathrm{C}$. Therefore, CQNU6-2 chitinase could be named as a thermostable enzyme. A comparable feature has been knowed by Cohnella sp. (ALIABADI et al, 2016), Paenibacillus thermoaerophilus (UEDA and KUROSAWA, 2015), Bacillus pumilus (BHATTACHARYA et al, 2016), Micrococcus sp. (ANNAMALAI et al, 2010). The strain CQNU6-2 could be considered as the producer of alkalitolerant and thermostable chitinase, which have the possibility to the bioconversion of chitin-containing materials under harsh $\mathrm{pH}$ or temperature conditions.

Metals ions and chemical compounds can interfere the activity of chitinase of the strain CQNU6-2 at both $0.01 \mathrm{mM}$ and $0.1 \mathrm{mM}$ concentration. Under the low concentration, most of the metals ions could increase the enzyme activity, such as $\mathrm{Na}^{+}, \mathrm{Ca}^{2+}, \mathrm{Fe}^{3+}, \mathrm{Cu}^{2+}$ and $\mathrm{Mg}^{2+}$. But when the concentration of $\mathrm{Cu}^{2+}$ and $\mathrm{Fe}^{3+}$ reached up to $0.1 \mathrm{mM}$, the enzyme activity was inhibited up to $50 \%$. Whether under high concentration or low concentration, Urea and EDTA have played the same effect on chitinase. Other chitinases produced by Micrococcus sp. (ANNAMALAI et al, 2010), Paenibacillus pasadenensis (GUO et al, 2017) and Bacillus pumilus (BHATTACHARYA et al, 2016) were also inhibited by $\mathrm{Fe}^{3+}$ and $\mathrm{Cu}^{2+}$. Chitinase from Bacillus pumilus (BHATTACHARYA et al, 2016) was activated by $\mathrm{Ca}^{2+}$. EDTA also interfered the chitinases from Paenibacillus pasadenensis (GUO et al, 2017) and Paenibacillus elgii (KIM et al, 2017), but acted as an activator to Cohnella sp. (ALIABADI et al, 2016).

Traditionally, shrimp shells and crab shells were used as the resources to generate commercialized chitin (DOAN et al, 2019). In addition, making effective use of these resources also can solve the problem of environmental pollution induced by shrimp shells waste. Colloidal chitin and shrimp shell powder were confirmed to be the ideal source of nutrients for strain CQNU6-2. And the strain can effectively hydrolyze colloid chitin and the degradation rate was up to $100 \%$ after 30 hours culture. Meanwhile, shrimp shells could be directly degraded by CQNU6-2 and the degradation rate reached the maximum of $65 \%$ after 4 days post inoculation. It indicated that this strain have the possibility to be developed to decompose the shrimp shells waste to bioactive substances and realize the environmental recycling of disposable chitin waste (ALI et al, 2020).

Chitinase was considered as one of the important enzymes applicated in industrial and commercial fields (GANGWAR et al, 2016). Although the crude chitinolytic enzymes from bacterium could be commercially used to chitin degradation (ALI et al, 2020), high purity and high activity of the enzyme were urgently required. The purified enzyme had wider application space and chitinase purified from Serratia marcescens (WANG et al, 2014), Salinivibrio sp. (LE and YANG, 2018), Aeromonas hydrophila (STUMPF et al, 2019) were purified and suggested to have potential application in biocontrol of aflatoxin, antifungal, producing chitobiose, degradation of chitin. The crude chitinase from strain CQNU6-2 were systematically studied here and was testified to have strong ability to decompose colloidal chitin and shrimp shells. Thus, it would be necessary to explore the purification of produced chitinase and the ammonium sulfate precipitation was employed to isolate chitinase from CQNU6-2. The results showed that the activity of chitinase were maximum when the saturation of ammonium sulfate was $40 \%$. This would provide a solid foundation for subsequent enzyme purification. Streptactin Affinity Chromatography (STUMPF et al, 2019), DEAE-cellulose chromatography (ALI et al, 2020), ultrafiltration and chitin sorption (AKTUGANOV et al, 2018) would be used as the main purification method to obtain the purified chitinase from strain CQNU6-2.

\section{Conclusions}

In conclusion, the Aeromonas sp. strain CQNU6-2 proved as a thermostable alkaline chitinase-producing organism. The characters of its highly stable enzyme system, which could be active under wide range of temperature and $\mathrm{pH}$, suggested a potential application in the industries of biomass utilization or biocontrol. Meanwhile, colloidal chitin and shrimp shell power could be used as carbon and nitrogen source for the strain growth and it can effectively hydrolyze colloidal chitin. Shrimp shells could be directly degraded by strain CQNU6-2, which performed its potential in biodegradation of shrimp shell waste to produce useful-bioactive substances.

\section{Acknowledgments}

This work was supported by National Natural Science Foundation of China (No. 31770160), the Science and Technology Research Program of Chongqing Municipal Education Commission (No. KJQN201800524), China Agriculture Research System (CARS-44-KXJ21).

\section{Conflict of Interest}

The authors have no conflict of interest to declare.

\section{References}

1. AJAYI A, ONIBOKUN E, GEORGE F, ATOLAGBE O. Isolation and characterization of chitinolytic bacteria for chitinase production from the African Catfish, Clarias gariepinus (Burchell, 1822). Res J Microbiol, 11:119-125 (2016).

2. AKTUGANOV G, GALIMZIANOVA N, GILVANOVA E, KUZMINA LY, BOYKO T, SAFINA V, MELENTIEV A. Characterization of Chitinase Produced by the Alkaliphilic Bacillus mannanilyticus IB-OR17 B1 Strain. Applied Biochemistry and Microbiology, 54(5): 505-511 (2018). 
3. AL-AHMADI KJ, YAZDI MT, NAJAFI MF, SHAHVERDI A, FARAMARZI M, ZARRINI G, BEHRAVAN J. Optimization of medium and cultivation conditions for chitinase production by the newly isolated: Aeromonas sp. Biotechnology, 7(2): 266-272 (2008).

4. ALI MH, ALJADAANI S, KHAN J, SINDI I, ABORAS M, ALY MM. Isolation and Molecular Identification of Two Chitinase Producing Bacteria from Marine Shrimp Shell Wastes. Pak J Biol Sci, 23(2): 139-149 (2020).

5. ALIABADI N, AMINZADEH S, KARKHANE AA, HAGHBEEN K. Thermostable chitinase from Cohnella sp. A01: isolation and product optimization. Brazilian journal of microbiology, 47(4): 931-940 (2016).

6. ANNAMALAI N, GIJI S, ARUMUGAM M, BALASUBRAMANIAN T. Purification and characterization of chitinase from Micrococcus sp. AG84 isolated from marine environment. African Journal of Microbiology Research, 4(24): 2822-2827 (2010).

7. BAHRAMI A, SHOJAOSADATI S, MOHEBALI G. Biodegradation of dibenzothiophene by thermophilic bacteria. Biotechnology letters, 23(11): 899-901 (2001).

8. BHATTACHARYA D, NAGPURE A, GUPTA RK. Bacterial chitinases: properties and potential. Crit Rev Biotechnol, 27(1): 21-8 (2007).

9. BHATTACHARYA S, DAS A, SAMADDER S, RAJAN SS. Biosynthesis and characterization of a thermostable, alkali-tolerant chitinase from Bacillus pumilus JUBCH08 displaying antagonism against phytopathogenic Fusariumoxysporum. 3 Biotech, 6(1): 87 (2016).

10. BRENNER DJ, KRIEG NR, STALEY JT, GARRITY GM. Bergey's Manual ${ }^{\circledR}$ of Systematic Bacteriology: Volume Two: The Proteobacteria, Part A Introductory Essays, Springer, Berlin (2005).

11. BUCHANAN R, GIBBONS N. Bergey's manual of determinative bacteriology $8^{\text {th }} \mathrm{ed}$., The Williams and Wilkins Co, Baltimore (1975).

12. CARDOZO FA, FACCHINATTO WM, COLNAGO LA, CAMPANA-FILHO SP, PESSOA A. Bioproduction of $\mathrm{N}$-acetyl-glucosamine from colloidal $\alpha$-chitin using an enzyme cocktail produced by Aeromonas caviae CHZ306. World Journal of Microbiology and Biotechnology, 35(8): 114 (2019).

13. CARDOZO FA, GONZALEZ JM, FEITOSA VA, PESSOA A, RIVERA ING. Bioconversion of $\alpha$-chitin into $\mathrm{N}$-acetyl-glucosamine using chitinases produced by marine-derived Aeromonas caviae isolates. World Journal of Microbiology and Biotechnology, 33(11): 201 (2017).

14. DAHIYA N, TEWARI R, HOONDAL GS. Biotechnological aspects of chitinolytic enzymes: a review. Appl Microbiol Biotechnol, 71(6): 773-82 (2006).

15. DAS S, DEY P, ROY D, MAITI MK, SEN R. N-Acetyl-D-glucosamine production by a Chitinase of marine fungal origin: a case study of potential industrial significance for valorization of waste chitins. Applied biochemistry and biotechnology, 187(1): 407423 (2019).

16. DEMIRJIAN DC, MORíS-VARAS F, CASSIDY CS. Enzymes from extremophiles. Current opinion in chemical biology, 5(2): 144-151 (2001).

17. DOAN CT, TRAN TN, NGUYEN VB, NGUYEN AD, WANG S-L. Production of a thermostable chitosanase from shrimp heads via Paenibacillus mucilaginosus TKU032 conversion and its application in the preparation of bioactive chitosan oligosaccharides. Marine drugs, 17(4): 217 (2019).

18. GANGWAR M, SINGH V, PANDEY AK, TRIPATHI C, MISHRA B. Purification and characterization of chitinase from Streptomyces violascens NRRL B2700. Indian J Exp Biol,54(1):64-71 (2016).

19. GUAN G, AZAD MAK, LIN Y, KIM SW, TIAN Y, LIU G, WANG H. Biological effects and applications of chitosan and chito-oligosaccharides. Frontiers in physiology, 10:516 (2019).

20. GUO S-H, CHEN J-K, LEE W-C. Purification and characterization of extracellular chitinase from Aeromonas schubertii. Enzyme and microbial technology, 35(6-7): 550-556 (2004).

21. GUO X, XU P, ZONG M, LOU W. Purification and characterization of alkaline chitinase from Paenibacillus pasadenensis CS0611. Chinese Journal of Catalysis, 38(4): 665-672 (2017).

22. HAKI G, RAKSHIT S. Developments in industrially important thermostable enzymes: a review. Bioresource technology, 89(1): 17-34 (2003).

23. HAN KI, PATNAIK BB, KIM YH, KWON HJ, HAN YS, HAN MD. Isolation and characterization of chitinase-producing Bacillus and Paenibacillus strains from salted and fermented shrimp, Acetes japonicus. Journal of food science, 79(4): M665-M674 (2014).

24. HSU S, LOCKWOOD J. Powdered chitin agar as a selective medium for enumeration of actinomycetes in water and soil. Appl Environ Microbiol, 29(3): 422-426 (1975).

25. HUBER JA, BUTTERFIELD DA, BAROSS JA. Temporal changes in archaeal diversity and chemistry in a mid-ocean ridge subseafloor habitat. Appl Environ Microbiol, 68(4): 1585-1594 (2002).

26. JHA S, MODI HA, JHA CK. Characterization of extracellular chitinase produced from Streptomyces rubiginosus isolated from rhizosphere of Gossypium sp. Cogent Food \& Agriculture, 2(1): 1198225 (2016). 
27. JUNG WJ, PARK RD. Bioproduction of chitooligosaccharides: present and perspectives. Mar Drugs, 12(11): 5328-56 (2014).

28. KANG Y, PAN X, XU Y, SIDDIQUI SA, WANG C, SHAN X, QIAN A. Complete genome sequence of the fish pathogen Aeromonas veronii TH0426 with potential application in biosynthesis of pullulanase and chitinase. Journal of biotechnology, 227:81-82 (2016).

29. KIM YH, PARK SK, HUR JY, KIM YC. Purification and characterization of a major extracellular chitinase from a biocontrol bacterium, Paenibacillus elgii HOA73. The plant pathology journal, 33(3): 318 (2017).

30. KRITHIKA S, CHELLARAM C. Isolation, screening, and characterization of chitinase producing bacteria from marine wastes. Int J Pharm Pharmac Sci, 8(5): 34-36 (2016).

31. KUMAR M, BRAR A, VIVEKANAND V, PAREEK N. Production of chitinase from thermophilic Humicola grisea and its application in production of bioactive chitooligosaccharides. International journal of biological macromolecules, 104:1641-1647 (2017).

32. KUZU SB, G VENMEZ HK, DENIZCI AA. Production of a thermostable and alkaline chitinase by Bacillus thuringiensis subsp. kurstaki strain HBK-51. Biotechnology research international, 2012:135498 (2012).

33. LE B, YANG SH. Characterization of a chitinase from Salinivibrio sp. BAO-1801 as an antifungal activity and a biocatalyst for producing chitobiose. Journal of basic microbiology, 58(10): 848-856 (2018).

34. LE B, YANG SH. Microbial chitinases: Properties, current state and biotechnological applications. World Journal of Microbiology and Biotechnology, 35(9): 144 (2019).

35. LIU K, DING H, YU Y, CHEN B. A Cold-Adapted Chitinase-Producing Bacterium from Antarctica and Its Potential in Biocontrol of Plant Pathogenic Fungi. Mar Drugs, 17(12):695 (2019).

36. MA Z, TANG J, LAN X, WEN H, CHEN Q, LI T, XU J, LI C, ZHOU Z. Isolation of a Thermostable Alkaline Cellulase-producing Bacterium Strain from a Garbage Dump. International Journal of Agriculture and Biology, 17(3) : 625-630 (2015).
37. RASTOGI G, MUPPIDI GL, GURRAM RN, ADHIKARI A, BISCHOFF KM, HUGHES SR, APEL WA, BANG SS, DIXON DJ, SANI RK. Isolation and characterization of cellulose-degrading bacteria from the deep subsurface of the Homestake gold mine, Lead, South Dakota, USA. Journal of industrial microbiology \& biotechnology, 36(4): 585 (2009).

38. RATHORE AS, GUPTA RD. Chitinases from Bacteria to Human: Properties, Applications, and Future Perspectives. Enzyme Res, 2015:791907 (2015).

39. SARIKAYA E, HIGASA T, ADACHI M, MIKAMI B. Comparison of degradation abilities of $\alpha$-and $\beta$-amylases on raw starch granules. Process Biochemistry, 35(7): 711-715 (2000).

40. SLIMENE IB, TABBENE O, GHARBI D, MNASRI B, SCHMITTER JM, URDACI MC, LIMAM F. Isolation of a chitinolytic Bacillus licheniformis S213 strain exerting a biological control against Phoma medicaginis infection. Appl Biochem Biotechnol, 175(7): 3494-506 (2015).

41. STUMPF AK, VORTMANN M, DIRKS-HOFMEISTER ME, MOERSCHBACHER BM, PHILIPP B. Identification of a novel chitinase from Aeromonas hydrophila $\mathrm{AH}-1 \mathrm{~N}$ for the degradation of chitin within fungal mycelium. FEMS microbiology letters, 366(1): fny294 (2019).

42. UEDA J, KUROSAWA N. Characterization of an extracellular thermophilic chitinase from Paenibacillus thermoaerophilus strain TC22-2b isolated from compost. World J Microbiol Biotechnol, 31(1): 135-43 (2015).

43. WANG K, YAN PS, CAO LX. Chitinase from a novel strain of Serratia marcescens JPP1 for biocontrol of aflatoxin: molecular characterization and production optimization using response surface methodology. BioMed research international, 2014: 482623(2014).

44. YAN N, CHEN X. Sustainability: Don't waste seafood waste. Nature, 524(7564): 155-7 (2015).

45. ZHANG D, XU D-H, QIU J, RASMUSSEN-IVEY CR, LILES MR, BECK BH. Chitin degradation and utilization by virulent Aeromonas hydrophila strain ML10-51K. Archives of microbiology, 199(4): 573-579 (2017). 